\title{
GEOMORPHOLOGICAL AND PALEOENVIRONMENTAL CHANGES OF ISMARIDA LAKE DURING HOLOCENE (N. GREECE)
}

\author{
Karadimou G. ${ }^{1}$, Vouvalidis K. ${ }^{1}$, Syrides G. ${ }^{2}$, Koukousioura O. ${ }^{2}$ and Aidona E. ${ }^{3}$ \\ ${ }^{1}$ Aristotle University of Thessaloniki, School of Geology, Department of Physical and Environment \\ al Geography, 54124, Thessaloniki, Greece, karadimg@gmail.com,vouval@geo.auth.gr \\ ${ }^{2}$ Aristotle University of Thessaloniki, School of Geology, Department of Geology, 54124, Thessalo \\ niki,Greece,syrides@geo.auth.gr,okoukous@geo.auth.gr \\ ${ }^{3}$ Aristotle University of Thessaloniki, School of Geology, Department of Geophysics, 54124, Thess \\ aloniki, Greece, aidona@geo.auth.gr
}

\begin{abstract}
In this research, the geomorphological and environmental changes of Lake Ismarida during Holocene are studied. Ismarida is located 20Km south of Komotini city and $5 \mathrm{Km}$ NNE of the archeological site of ancient Stryme at Rhodope Province, (N. Greece). The analysis of geomorphological, paleontological, sedimentological and magnetic susceptibility data as well as the evaluation of ${ }^{14} \mathrm{C}$ datings, showed that four environmental units are recognized in the lake sediments. The environment changed from shallow marine to open lagoonal of low energy ( 5400-3400 years BP), to shallow marine to open lagoonal of high energy ( 3400-3000 years BP), subsequently turned into brackish to lagoonal with fresh water inputs ( 3000-2000 years BP), and finally formed to fluvial-terrestrial, until present time. The Lake Ismarida as it is known today was formed 2000 years BP on the isolated western part of the preHolocene valley between the deltaic deposits of the rivers Filiouris and Vosvozis. Keywords: lake geomorphology, paleogeopraphy, paleoenvironment, magnetic susceptibility, Filiouris River.

\section{Пєрí $\eta \psi \eta$}

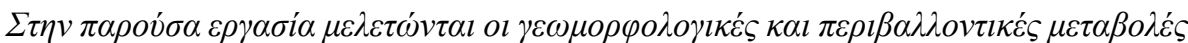

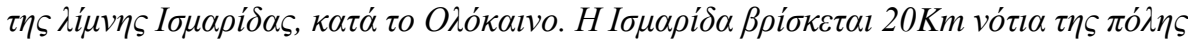

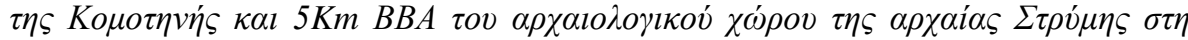

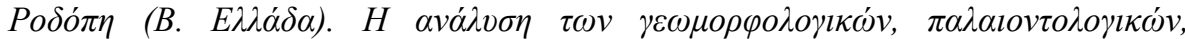

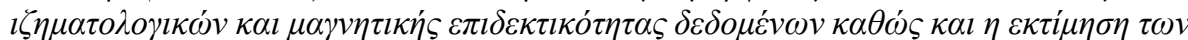

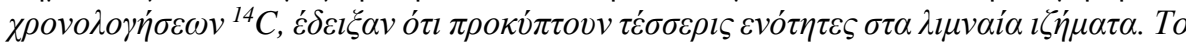

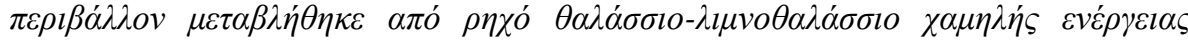

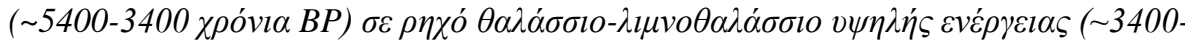

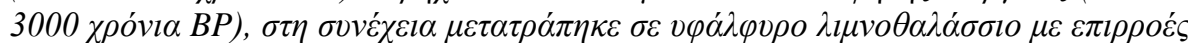

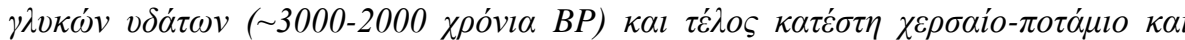

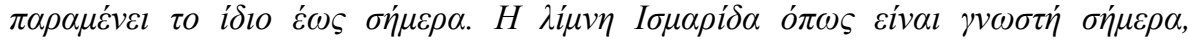

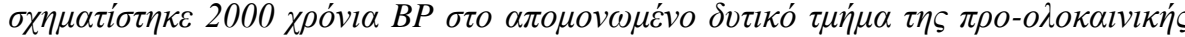

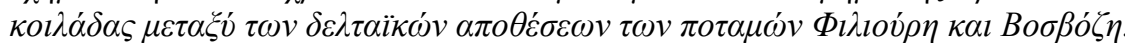




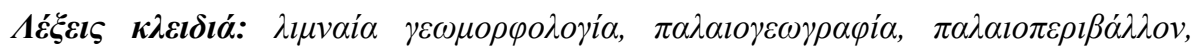

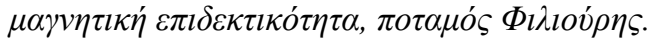

\section{Introduction}

In the last decade, many studies have been performed in several Greek coastal, providing information about paleoenvironmental changes during Holocene (Syrides et al., 2008, 2009a, 2009b; Vouvalidis et al., 2010; Koukousioura et al., 2012; Triantaphyllou et al., 2010). Lake Ismarida is a Ramsar protected area situated at the deltaic plain of the Vosvozis River and the Filiouris River. Many researchers have studied the lake as well as the Vosvozis River during the last years, covering different scientific aspects. Pisinaras et al. (2007), developed a groundwater flow model for water resources management in the Ismarida plain and Giannopoulos (2008), developed models for preventing and monitoring pollution at Vosvozis River. Moustaka et al. (2011), studied the phytoplankton and zooplankton of Ismarida and Katsavouni and Papadimos (2012a, 2012b), studied the physical and chemical parameters that affect ecology and biology of the lake. Additionally, Tsiaras and Nikisianis (2014), studied how tourism influences the protected sites.

The aim of this research is to study the geomorphological and paleoenvironmental changes of Ismarida Lake during Holocene, by taking into account the geomorphological, lithological, paleontological and magnetic susceptibility data.

\section{Geological-Geomorphological Setting}

Lake Ismarida administratively belongs to Komotini Municipality of Eastern Macedonia and Thrace Province. It is located at the southern part of Rhodope Province, 20Km south of the city of Komotini. Pagouria village is located at the north side of the lake, Neo Sidirochori village at the north-east and Imeros village at the south-east. Ismarida Lake is located $5 \mathrm{Km}$ north-northeast of the archeological site of ancient Stryme and 7Km north-east of Molyvoti headland.

Ismarida Lake is the only natural shallow lake containing fresh water at the northern Greece. The maximum lake surface is about $3 \mathrm{Km} 2$, while the mean depth is about $1 \mathrm{~m}$. Vosvozis River supplies Ismarida Lake with fresh water, flowing into the lake at the northern part. Both the lake and the river are parts of the Komotini drainage system, included in the 12th water management district of Thrace. The total area of its drainage basin occupies $366 \mathrm{Km} 2$. In the eastern part of the lake, Filiouris River is located, flowing into the North Aegean Sea (Figure 1) and creating its deltaic plain between Ismarida Lake and the North Aegean coastline. During heavy rainfall periods the river's overbank flow floods the lower area of the lake surroundings.

Ismarida Lake is located at the wider area of the Rhodope geotectonic Massif. This wider area includes the Rhodope Mountains at Thrace, south Bulgaria and part of Eastern Macedonia reaching Strymon River as the western limit. Neogene sediments delimit the lake on the west, while on the northern and eastern part of the lake Quaternary alluvial sediments appear (Bousbouras et al., 2010).

The lake sediments of the area dated to Holocene Era. The lake bottom is covered by silty sediments deposited during various phases of lacustrine sedimentation. At the peripheral area of the lake, sandstones and sediments of sandy marls and sandy clay are spotted. At certain parts, undifferentiated conglomerates are located (Bousbouras et al., 2010). 


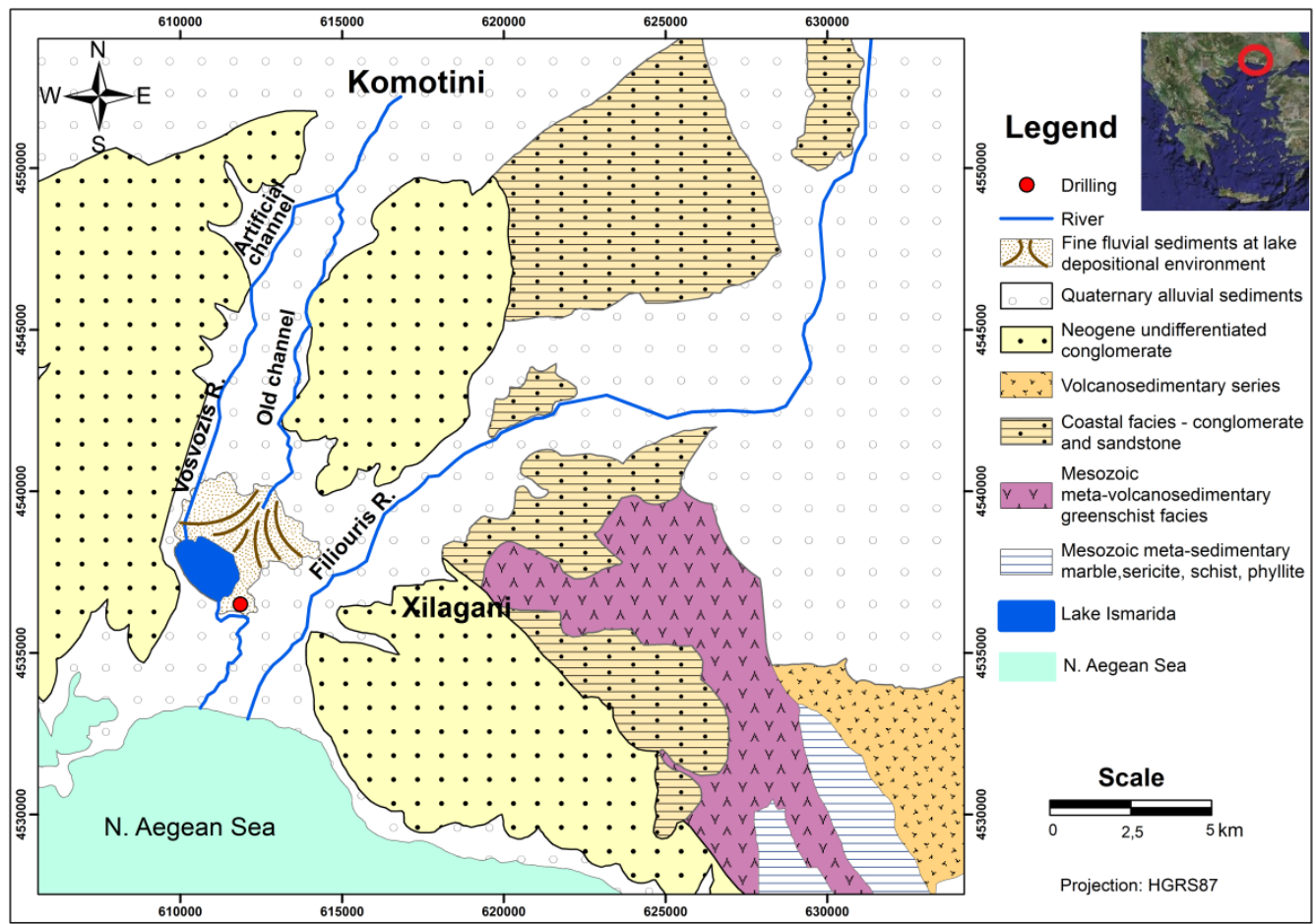

Figure 1 - Geological map of Ismarida Lake and the surrunding area, (modified from IGME, Dimadis and Zachos, 1986).

\section{Methodology}

\section{Borehole data}

The main sampling process determining subsurface stratigraphy was vibracoring. The sediment cores were obtained by using an Atlas Copco vibracoring device (Cobra MK 1). The 1m in length corer used, was equipped with a $40 \mathrm{~mm}$ in diameter core cutter and a basket type core catcher. The inner sampling was achieved by using plastic PVC tubes with a $40 \mathrm{~mm}$ outer diameter. After sampling, all the tubes were sealed in order to avoid loss of humidity, marked and stored properly for further analysis. The maximum recovery depth was $5.80 \mathrm{~m}$ below surface.

\section{Magnetic Susceptibility}

The magnetic susceptibility volume of core sediments was measured by using a Bartington MS2C Core Logging Ring Sensor. A total of 288 measurements were obtained using a $2 \mathrm{~cm}$ step.

\section{Sampling - Laboratory analysis}

By dividing the core samples, stratigraphic description and photographic record were allowed. 191 selective samples using $2.5 \mathrm{~cm}$ step, or denser when needed, were collected from the undisturbed parts of the vibracores. After oven dried up at $40 \mathrm{oC}$, samples of $\sim 10 \mathrm{~g}$ were separated and weighted. All samples were treated with $30 \% \mathrm{H} 2 \mathrm{O} 2$ and washed with normal water into a stainless steel sieve of $0.063 \mathrm{~mm}$ wire mesh, for paleontological analysis. All the samples were inspected under a JENA stereoscope and all the fossils (gastropods, bivalves, etc.) were handpicked, sorted and stored into small glass and plastic vials. The finest parts of the samples $(<0.063 \mathrm{~mm})$, were collected for further sedimentological study. The complete individuals of gastropods and the isolated valves of bivalves were taken under concern in terms of determining environmental facies. Total samples were studied 
for paleontological purposes. All sorted shells were counted and afterwards total number and density/10g of dry sediment was calculated. Although the crushed shells and shell fragments were present in many samples, only complete individuals were considered for further paleontological analysis and interpretation.

\section{${ }^{14} C$ Dating}

Four radiocarbon age determinations of in situ marine shells and plants of ISMR-2 borehole were obtained by AMS technique (Table 1). All the samples were submitted to BETA ANALYTIC INC., Miami, Florida, USA. The conventional radiocarbon ages of the marine shells have been calibrated in calendar years after IntCal13 by using MARINE13 curve for marine data (Reimer et al., 2013).

\section{Maps and Aerial photographs - Positioning and GIS}

The maps produced derived from processing aerial photographs from Hellenic Military Geographical Service (H.M.G.S.) using GIS software. All the coordinates are in Hellenic Geodetic Reference System 1987 (HGRS87). The borehole coordinates were obtained with a TRIMPLE R-6 receiver. In order to ortho-rectify the aerial photographs, GPS measurements were also obtained with a Garmin GPSmap 60CSx device. Various points of interest around the lake that identified on aerial photographs, like human constructions etc., were selected as control points.

\section{Results}

\subsection{Geomorphological changes}

Lake Ismarida and the surrounding lowland area has undergone a considerable evolution since 1945. The key factors for the lake and the plain evolution are respectively the construction of a side wall at the east shoreline of the lake in 1976 and the construction of the new artificial channel of Vosvozis River westwards of its old channel (Figure 1).

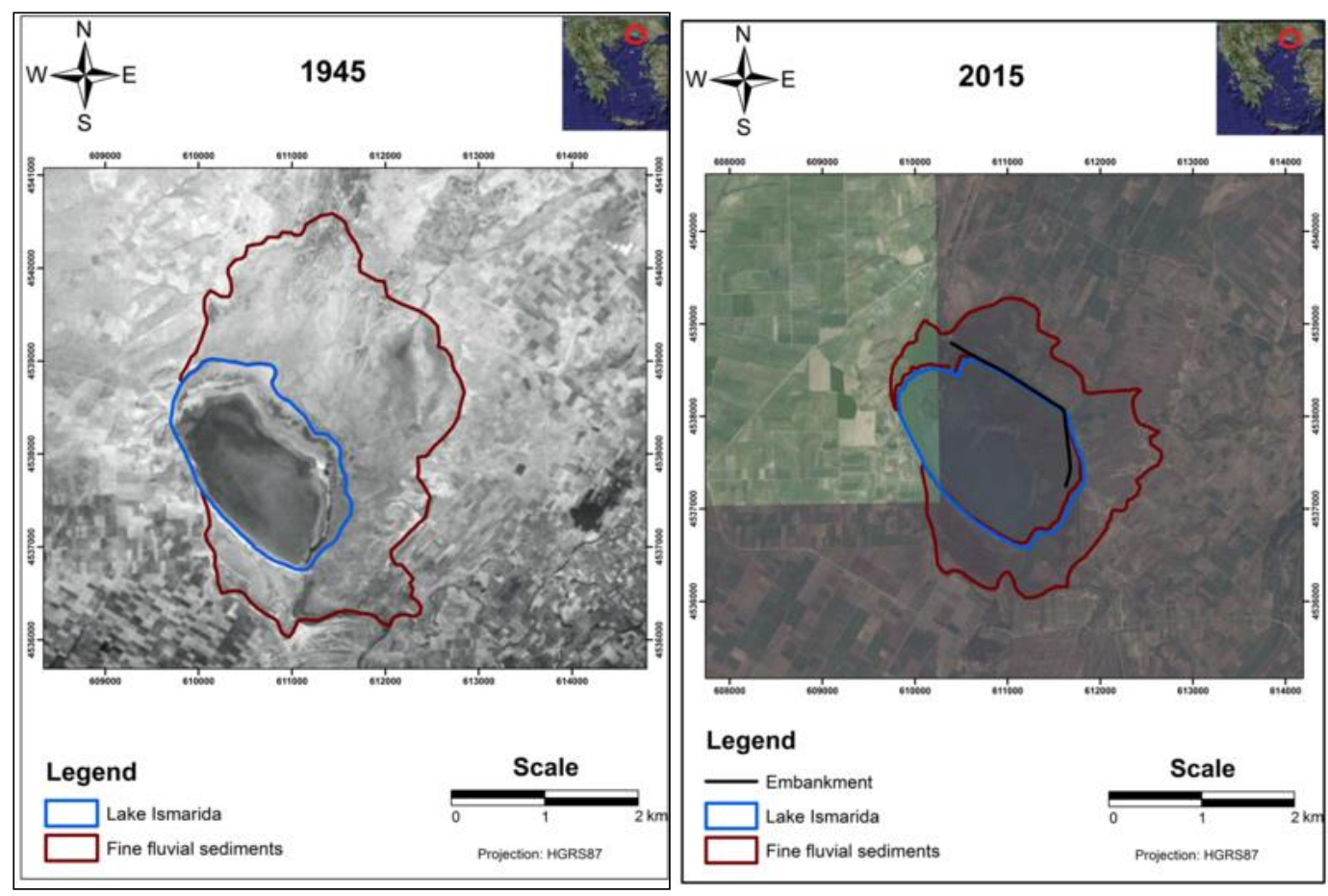

Figure 2 - a) maximum surface of Ismarida Lake (blue line) and the lake delta (red line) in 1945, b) maximum surface of Ismarida Lake (blue line) and the lake delta (red line) in 2015. 
According to the aerial photograph of 1945 (Figure 2), the surface of the lake is $2.77 \mathrm{Km} 2$ and the area of the lake delta with fine grained sediments is $6.67 \mathrm{Km} 2$. Until 1976, the Vosvozis River channel reaching the lake side from northeast creating a lake delta fan with a length of its longidudinal axis about $2 \mathrm{Km}$.

Since 1976, because of the new artificial channel construction (Figure 1), the river channel enters the lake from the north side, deviating its initial course from the old lake delta. Since then the sediment deposition takes place in the lake reservoir. As a result of this artificial channel construction, the old floodplain of the lake delta is not supplied with fine river sediments anymore.

Today, the maximum lake surface is $2.65 \mathrm{Km} 2$ whereas the minimum is $1.18 \mathrm{Km} 2$ and the area of the old lake delta is only $3.30 \mathrm{Km} 2$ (Figure 2). The volume of the lake reservoir is continuously being reduced due to the depositional process of the Vosvozis River. Additionally, there is a change of the physical and chemical parameters of the lake water causing changes in aquatic vegetation (reed expansion).

\subsection{Lithology and molluscan composition}

A borehole (ISMR-2) was drilled at the south-east side of lake Ismarida $(0.81 \mathrm{~m}$ above m.s.1., $5.80 \mathrm{~m}$ depth, x: 611885.718; y: 4536536.64) is depicted in Figure 1. Molluscs were found into 148 samples from the 191 of the borehole $(1.49 \mathrm{~m}-5.73 \mathrm{~m}$ depth). The fauna of gastropods comprises Bittium spp., Cerithium spp., Rissoa spp., Cyclopes sp., Caecum spp., Hydrobia sp., Retusa spp., Planorbis sp., Potamides sp. and Gibula sp., and the fauna of bivalves comprises Loripes sp., Parvicardium sp, Venus spp., Tapes sp., Donax sp., Plagiocardium sp., Glycymeris sp., Cerastoderma sp., Abra sp., Mactra sp., Dosinia sp., Clausinella sp., Corbula sp., Barbatia sp., Arca sp., Pecten sp. and Mytilus sp. (Figure 4b). In some samples organic matter, plants, Echinoidea, Crustacea and scaphopoda such as Dentalium sp. were found.

Facies determination is based on macro-faunal analyses from the borehole studied samples. At vibracore profile ISMR-2, four distinguished units are distinct.

The upper part, $0.00 \mathrm{~m}-1.49 \mathrm{~m}$ (Unit 1), consists of sandy mud to mud sediments (Figure 3, 4) and lacks invertebrate fauna.

The middle part, $1.49 \mathrm{~m}-3.68 \mathrm{~m}$ (Unit 2), consists of sandy mud to silty sand sediments (Figure 3, 4). A molluscs fauna is present, containing abundant Cerastoderma sp., Abra sp., Mactra sp. (max. 11/10g) and Bittium spp. (max. 29/10g), also accompanied by Rissoa spp., Caecum spp., Loripes sp., Parvicardium sp., Echinoid and Crustacean fragments.

The next part, 3.68m - 4.54m (Unit 3), consists of muddy sand sediments (Figure 3, 4). Molluscs are present, abundantly with Bittium spp. and Parvicardium sp. (max. 42/10g), Loripes sp., and Dosinia sp., and with lower values with Cerithium spp., Rissoa spp., Caecum spp, Tapes sp., Donax sp., Echinoids, Crustacean and a small concentration of Veneridae. At this part, Cerastoderma sp., Abra sp. and Mactra sp. are totally absent.

The base part, 4.54m - 5.80m (Unit 4), consists of silty sand sediments (Figure 3, 4). Mollusc fauna mainly represented by Bittium spp. (max. 47/10g), Veneridae (max. 12/10g), Cerastoderma sp. and Mactra sp. (max. 22/10g), followed by Cerithium spp., Rissoa spp., Caecum spp., Hydrobia sp., Parvicardium sp., Donax sp., Plagiocardium sp., Dosinia sp., Clausinella sp., Arca sp., Mytilus sp., Echinoids and Crustacean. At this part, the higher concentration of Veneridae was noticed in total borehole sequence. 


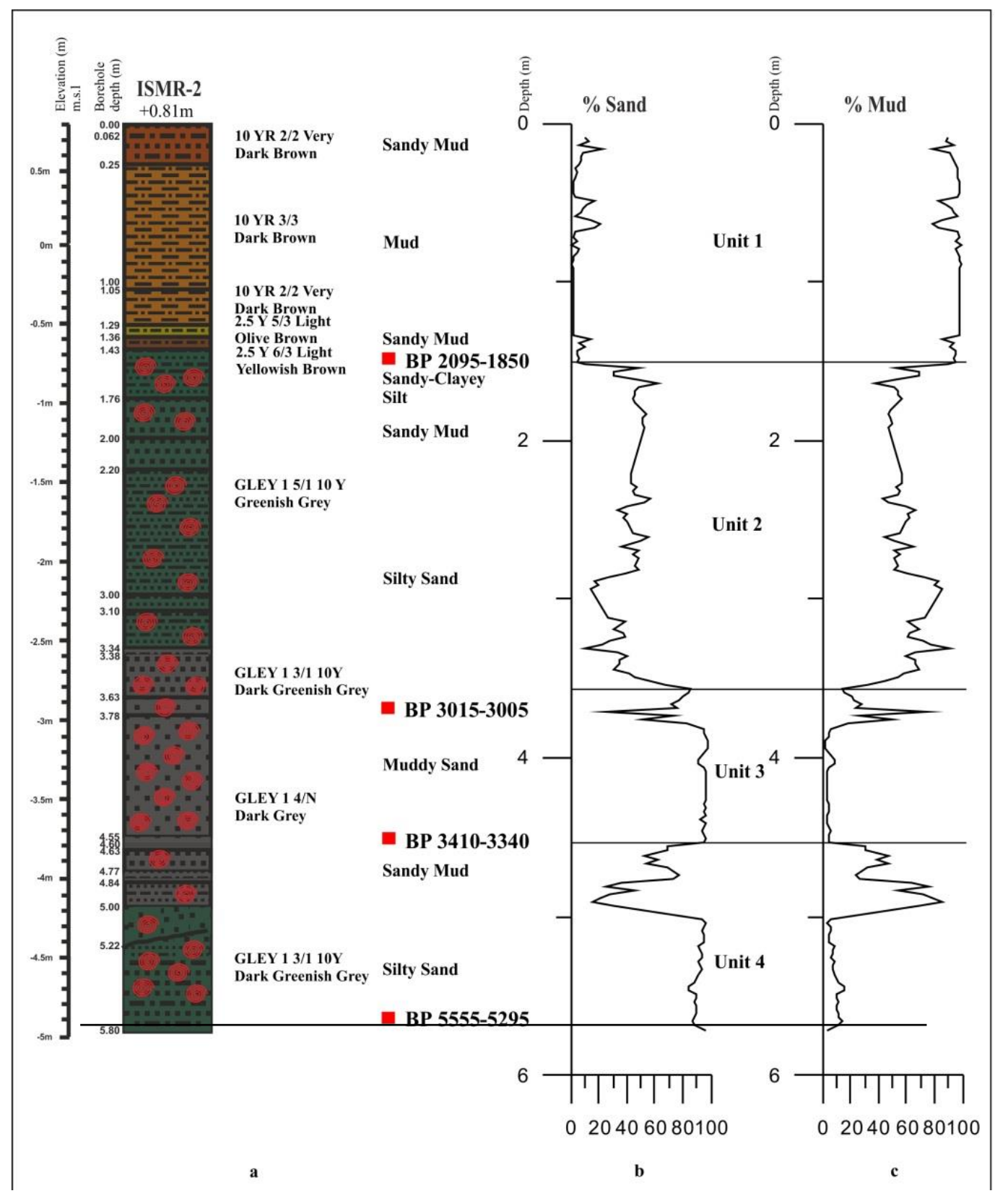

Figure 3 - a) Lithology of the ISMR-2 borehole, b) Relative frequencies of sand, c) Relative frequencies of mud. 


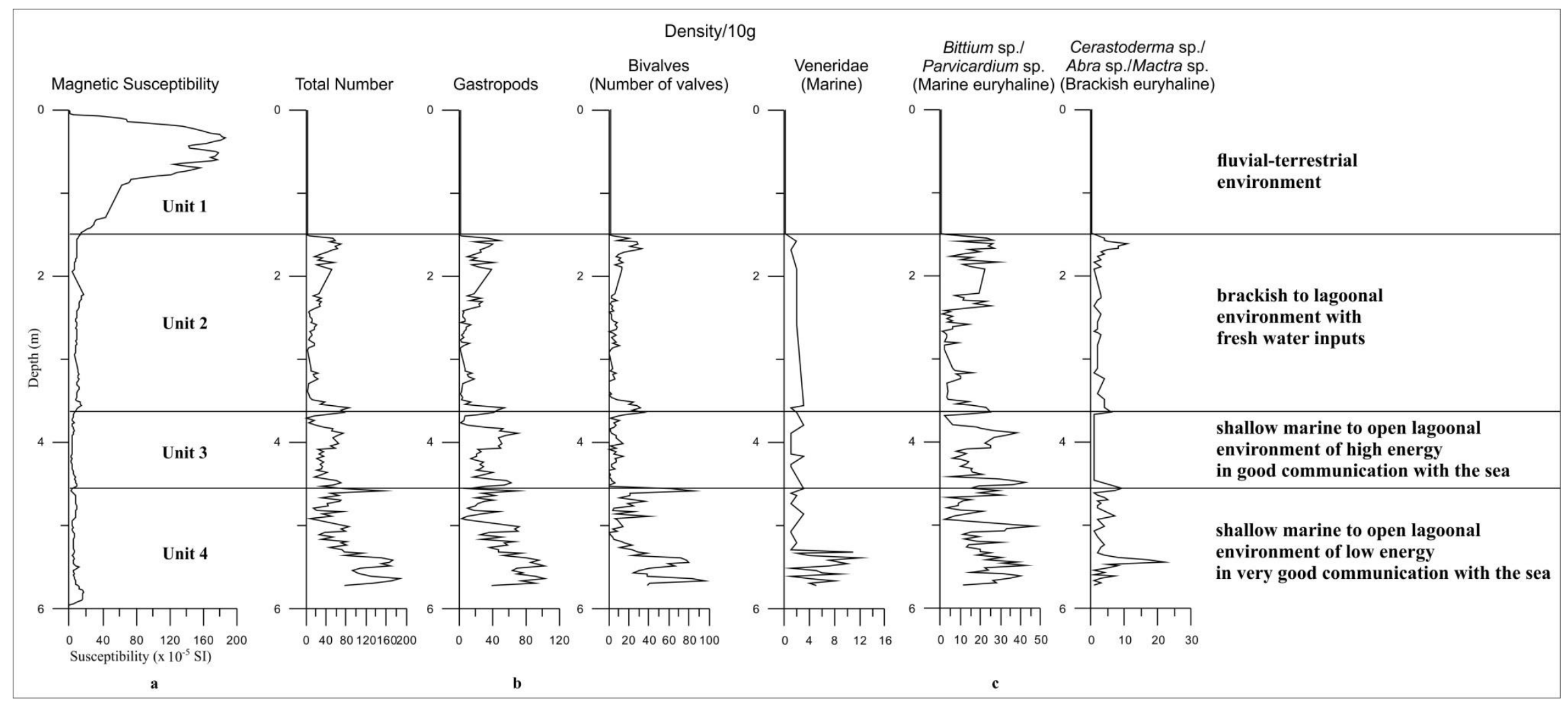

Figure 4 - a) Magnetic Susceptibility, b) Molluscan abundances/10g, c) Abundances/10g of the most common molluscan taxa. 


\subsection{Magnetic Susceptibility}

Figure 4a shows the variation of the magnetic susceptibility along the core. The higher values of the whole core are revealed in the upper part of the borehole at $0.00 \mathrm{~m}-1.49 \mathrm{~m}$ depth (Unit 1), reaching $186.2 \times 10-5$ SI. At $1.49 \mathrm{~m}-5.80 \mathrm{~m}$ depth (Unit 2, Unit 3, Unit 4), the values differentiate and range at lower rate between $2.1 \times 10-5$ SI and $17.2 \times 10-5$ SI with the maximum value at $2.22 \mathrm{~m}$ depth.

\section{4. ${ }^{14} \mathrm{C}$ Dating}

Four samples of marine shells and plants, from the borehole ISMR-2 were dated with the 14C-AMS method. The type of dated materials, their depth below present mean sea level and their calibrated age, are presented in Table 1.

Table 1 - Radiocarbon dating results for borehole samples of Ismarida Lake, calibrated after IntCal13 (Reimer et al., 2013).

\begin{tabular}{cccccc}
\hline $\begin{array}{c}\text { Sample Code/ } \\
\text { Lab. number }\end{array}$ & $\begin{array}{c}\text { Depth (m) } \\
\text { b.m.s.l. }\end{array}$ & Material & $\begin{array}{c}{ }^{\mathbf{1 3}} \mathbf{C} /{ }^{\mathbf{1 2}} \mathbf{C} \text { Ra } \\
\text { tio (\%o) }\end{array}$ & $\begin{array}{c}\text { Conventional } \\
\text { R/C Age }\end{array}$ & 2 $\boldsymbol{\sigma}$ Calibrated age \\
\hline $\begin{array}{c}\text { 12-ISMR2-155/ } \\
\text { Beta - 397441 }\end{array}$ & 0.74 & Shell & -1.4 & $2490+/-30$ BP & $\begin{array}{c}\text { Cal BC 145 - AD 100 } \\
\text { (Cal BP 2095-1850) }\end{array}$ \\
$\begin{array}{c}\text { 13-ISMR2-373/ } \\
\text { Beta - 397442 }\end{array}$ & 2.92 & Plant & -14.4 & $2960+/-30$ BP & $\begin{array}{c}\text { Cal BC 1065-1055 } \\
\text { (Cal BP 3015-3005) }\end{array}$ \\
$\begin{array}{c}\text { 14-ISMR2-459/ } \\
\text { Beta - 397443 }\end{array}$ & 3.78 & Plant & -13 & $3150+/-30$ BP & $\begin{array}{c}\text { Cal BC 1460-1390 } \\
\text { (Cal BP 3410-3340) }\end{array}$ \\
$\begin{array}{c}\text { 15-ISMR2-564/ } \\
\text { Beta - 397444 }\end{array}$ & 4.83 & Shell & +1.4 & $5210+/-30$ BP & $\begin{array}{c}\text { Cal BC 3605-3345 } \\
\text { (Cal BP 5555-5295) }\end{array}$ \\
\hline
\end{tabular}

\section{Discussion and synthesis}

\subsection{Environmental identification}

The obtained data of the present study indicate that the four units recognized from the lithological and molluscan analyses (described above) can be distinguished, from the oldest to youngest as follow (Figure 4):

Unit 4 (4.54m - 5.80m depth): In this Unit, silty sand sediments with low values of magnetic susceptibility appear. These results, in combination with the abundance of brackish euryhaline molluscs Cerastoderma sp. and Mactra sp., of marine euryhaline mollusc Bittium spp. and of marine molluscs Veneridae, indicate a shallow marine to open lagoonal environment of low energy in very good communication with the sea (Sakellariou, 1957; Syrides, 2008; Liu et al., 2012).

Unit 3 (3.68m - 4.54m depth): This Unit consists of muddy sand sediments. The abundance of marine euryhaline molluscs Bittium spp. and Parvicardium sp. brackish euryhaline mollusc Mactra sp., in combination with low values of magnetic susceptibility at sediments, indicate a shallow marine to open lagoonal environment of high energy in good communication with the sea.

Unit 2 (1.49m - 3.68m depth): In Unit 2, brackish euryhaline molluscs Cerastoderma sp., Abra sp., and Mactra sp. and of marine euryhaline Bittium spp. and Parvicardium sp. are abundant. This fauna in combination with sandy mud to silty sand sediments with low values of magnetic susceptibility, indicate a brackish to lagoonal environment with fresh water inputs.

Unit $1(0.00 \mathrm{~m}-1.49 \mathrm{~m}$ depth): the sandy mud to mud sediments with high values of magnetic susceptibility and lack of mollusc fauna indicate a fluvial - terrestrial environment. 


\subsection{Holocene paleoenvironmental changes: paleogeography}

Evaluation of the aforementioned geomorphological, lithological, paleontological, chronological and magnetic susceptibility data allows determination of paleoenvironmental changes in Ismarida Lake and its surrounding lowland area. According to this scenario, before $\sim 5400$ to $~ 3400$ years the area of interest was at good communication with the sea, and the environment was shallow marine to open lagoonal of low energy. Probably, the area was the inner part of a bay created by the sea transgression which covered the pre-Holocene paleosurface of the Vosvozis and Filiouris river valleys. The area at $\sim 3400$ years BP to $\sim 3000$ years BP, remained in good communication with the sea at a shallow marine to open lagoonal environment, but subsequently changed into high energy. This bay was open from south, allowing high energy waves with a south-north orientation to arrive at the beach creating a wave dominated coast. This is proved by the lack of mollusc Cerastoderma sp. and the rapid sedimentation. The shallow marine environment gradually turned into brackish to lagoonal with fresh water inputs, and remained like this for 1000 years. This occurred before $\sim 3000$ years due to the deltaic prolongation of the Filiouris River. The area of the lake was isolated and the open communication with the sea was interrupted. Finally, at 2000 years BP a fresh water lake was formed. The Filiouris River delta plain was developed further southwards isolating the area from the sea. The area turned into a fluvial-terrestrial environment silted by fine grained sediments derived from Vosvozis River and overbank flow of Filiouris River.

\section{Conclusions}

The study area has gradually evolved from a shallow marine to a fluvial-terrestrial environment during upper Holocene. At 3000 years BP the water communication between the lake and the sea interrupted due to fluvial process of the Filiouris River. The lake as it is known at present time was formed years later, when it was cut off by the deltaic plain of Filiouris River. The new deltaic plain of Filiouris is now located at the south of the lake. The lake was formed on the isolated western part of the pre-Holocene valley between the elevated deltaic deposits of Filiouris River and the alluvial fan of Vosvozis River further northwards. Nowadays, Lake Ismarida is supplied with fresh water only by Vosvozis River. The coarse sediments of the river are still deposited at the plain further northwards and only the fine sediments are transferred and deposited into the lake.

\section{Acknowledgments}

The authors would like to thank the "Molyvoti Project" headed by Professor Nathan Arrington, Department of Art and Archeology, Princeton University, for the financial support to cover the expenses of the 4 AMS datings of the research. We also thank Dr. Chris Pennos for his assistance in fieldwork.

\section{References}

Bousbouras, D., Panagiotopoulou, M., Kazoglou, G., Fotiadis, G. and Klados, G., 2010. Definition and description study of required interventions for the optimal management of reed vegetation of Ismarida Lake, Greece, 144 pp. (In Greek).

Giannopoulos, P.C., 2008. Establishing low cost methodology for rapid forecasting and monitoring pollution at rivers, University of Patras, Department of Civil Engineering, Environmental Engineering Laboratory, Patras, Greece, 166 pp. (In Greek).

I.G.M.E., 1986. Geological map of Rhodope Massif 1:200.000, Dimadis E. and Zachos S.

Katsavouni, S. and Papadimos, D., 2012a. Evaluation of functions and values in Lake Ismarida. Thessaloniki, The Goulandris Natural History Museum - Greek Biotope/Wetland Centre, Thermi, Greece, 46 pp. (In Greek).

Katsavouni, S., Papadimos, D. and Doulgeris, Ch., 2012b. Identification of changes in land use around Lake Ismarida, The Goulandris Natural History Museum - Greek Biotope/Wetland Centre, Thermi, Greece, 26 pp. (In Greek). 
Koukousioura, O., Triantaphyllou, M.V., Dimiza, M.D., Pavlopoulos, K., Syrides, G. and Vouvalidis, K., 2012. Benthic foraminiferal evidence and paleoenvironmental evolution of Holocene coastal plains in the Aegean Sea (Greece), Quaternary International, 261, 105117.

Liu, Q., Roberts, A., Larrasoaña, J., Banerjee, S., Guyodo, Y., Tauxe, L. and Oldfield, F., 2012. Environmental Magnetism: Principles and applications, Reviews of Geophysics, 50, 393-442.

Moustaka, M., Michaloudi, E., Katsiapi, M., Genitsaris, S., Charalampous, E. and Vourka, A., 2011. Monitoring of Lake Ismarida and exploration of the food chain within the frame of restoration actions, The Goulandris Natural History Museum - Greek Biotope/Wetland Centre, Aristotle University of Thessaloniki, School of Biology, Thessaloniki, Greece, 90 pp. (In Greek).

Pisinaras, V., Petalas, C., Tsihrintzis, V.A. and Zagana, E., 2007. A groundwater flow model for water resources management in the Ismarida plain, North Greece, Environmental Modeling and Assessment, 12, 75-89.

Reimer, P.J., Bard, E., Bayliss, A., Beck, J.W., Blackwell, P.G., Bronk Ramsey, C., Buck, C. E., Cheng, H., Edwards, R.L., Friedrich, M., Grootes, P.M., Guilderson, T.P., Haflidason, H., Hajdas, I., Hatte, C., Heaton, T.J., Hoffmann, D.L., Hogg, A.G., Hughen, K.A., Kaiser, K.F., Kromer, B., Manning, S.W., Niu, M., Reimer, R.W., Richards, D.A., Scott, E.M., Southon, J.R., Staff, R.A., Turney, C.S.M. and van der Plicht, J., 2013. IntCal13 and Marine13 radiocarbon age calibration curves 0-50,000 years cal BP, Radiocarbon, 55(4), 1869-1887.

Sakellariou, E., 1957. Artigas molluscs of Thessaloniki gulf and their contribution to stratigraphy, Athens, Greece, Geological Annals of Greek territory, 8, 135-221. (In Greek).

Syrides, G., 2008. Marine mollusk fauna and Holocene stratigraphy of the marsh of Agia Paraskevi, (Lamia, Fthiotida) Greece, Bulletin of the Geological Society of Greece.

Syrides, G., Albanakis, K., Vouvalidis, K., Pilali-Papasteriou, A., Papaefthimiou-Papanthimou, A., Ghilardi, M., Fouache, E., Paraschou, T. and Psomiadis, D., 2009a. Holocene Palaeogeography of the Northern Margins of Giannitsa Plain in relation to the Prehistoric Site of Archontiko (Macedonia-Greece), Z. Geomorph. N.F., 53, 71-82.

Syrides, G., Vouvalidis, K., Albanakis, K., Tsourlos, P. and Matsas, D., 2009b. Palaeogeographical Evolution and Sea Level Changes during Holocene in the Prehistoric Settlement of Mikro Vouni (Samothrace Island, Greece), Z. Geomorph. N.F., 53, 39-45.

Triantaphyllou, M.V., Kouli, K., Tsourou, T., Koukousioura, O., Pavlopoulos, K. and Dermitzakis, M.D., 2010. Paleoenvironmental changes since 3000 BC in the coastal marsh of Vravron (Attica, SE), Greece, Quaternary International, 216, 14-22.

Tsiaras, D. and Nikisianis, N., 2014. Compilation of specifications that ensure the non-disturbance of wildlife and the integrity of the protective objects, Report 11 of project: Development of tourism and management of visitors at the protected area of the National Park of East Macedonia and Thrace, January 2014, Delta Nestos Lakes Vistonida-Ismarida Management Body, Independent version, Greece, 34 pp. (In Greek).

Vouvalidis, K., Syrides, G., Pavlopoulos, K., Papakonstantinou, M. and Tsourlos, P., 2010. Holocene palaeoenvironmental changes in Agia Paraskevi prehistoric settlement, Lamia, Central Greece, Quaternary International, 216, 64-74. 